\title{
Purification and properties of a novel
} CrossMark quizalofop-p-ethyl-hydrolyzing esterase involved in quizalofop-p-ethyl degradation by Pseudomonas sp. J-2

\author{
Hui Zhang, Mengya Li, Jie Li, Guangli Wang* and Yuan Liu*
}

\begin{abstract}
Quizalofop-p-ethyl (QPE) is a post-emergence herbicide that effectively controls grass weeds and is often detected in the environment. However, the biochemical and molecular mechanisms of QPE degradation in the environment remains unclear. In this study, a highly effective QPE-degrading bacterial strain J-2 was isolated from acclimated activated sludge and identified as a Pseudomonas sp., containing the QPE breakdown metabolite quizalofop acid (QA) identified by Liquid Chromatography-Ion Trap-Mass Spectrometry (LC-IT-MS ${ }^{n}$ analysis. A novel QPE hydrolase esterase-encoding gene qpeH was cloned from strain J-2 and functionally expressed in Escherichia coli BL21 (DE3). The specific activity of recombinant QpeH was $198.9 \pm 2.7 \mathrm{U} \mathrm{mg}^{-1}$ for QPE with $K_{m}$ and $K_{\text {cat }}$ values of $41.3 \pm 3.6 \mu \mathrm{M}$ and $127.3 \pm 4.5 \mathrm{~s}^{-1}$. The optimal $\mathrm{pH}$ and temperature for the recombinant QpeH were 8.0 and $30^{\circ} \mathrm{C}$, respectively and the enzyme was activated by $\mathrm{Ca}^{2+}, \mathrm{Cd}^{2+}, \mathrm{Li}^{+}, \mathrm{Fe}^{3+}$ and $\mathrm{Co}^{2+}$ and inhibited by $\mathrm{Ni}^{2+}, \mathrm{Fe}^{2+}, \mathrm{Ag}^{+}, \mathrm{DEPC}, \mathrm{SDS}$, Tween 80, Triton $X, \beta$-mercaptoethanol, PMSF, and PCMB. In addition, the catalytic efficiency of QpeH toward different AOPP herbicides in descending order was as follows: fenoxaprop-P-ethyl > quizalofop-P-tefuryl > QPE > haloxyfop-P-methyl > cyhalofopbutyl > clodinafop-propargyl. On the basis of the phylogenetic analysis and multiple sequence alignment, the identified enzyme QpeH, was clustered with esterase family V, suggesting a new member of this family because of its low similarity of amino acid sequence with esterases reported previously.
\end{abstract}

Keywords: Quizalofop-p-ethyl, Biodegradation, qpeH, Metabolic pathway, Pseudomonas sp

\section{Background}

Quizalofop-p-ethyl (QPE; ethyl(R)-2-[4-(6-chloroquinoxalin-2-yloxy) phenoxy] propionate) is a member of the aryloxyphenoxypropionate (AOPP) group of herbicides. Like other members of this family, QPE is a selective post-emergence herbicide that is registered for use in the control of annual and perennial grass weeds in crops of potatoes, soya beans, sugar beets, peanuts, oilseed rape, sunflowers, vegetables, cotton, flax, and other broad leafed plants $[1,2]$. As a systemic herbicide that inhibits acetyl CoA carboxylase, QPE is absorbed from the leaf surface and translocated throughout the plant via the

\footnotetext{
*Correspondence: wanf-3344@163.com; liuyuan0813@aliyun.com College of Life Sciences, Huaibei Normal University, Huaibei 235000, China
}

xylem and phloem, from the treated foliage to the root system, and accumulates in the meristematic tissue, thus inhibiting fatty acid biosynthesis [3].

The widespread use of QPE has led to detrimental effects on the environment. Several publications have reported that QPE and its metabolites have reproductive, genetic and liver toxicity $[4,5]$, as well as being a raw water contaminant [6]. Thus, the cleanup of QPE residues is an important part of environmental remediation [7]. The use of microbes and enzymes in the detoxification and decontamination of AOPP herbicides is considered a and environment-friendly approach. To date, only mented, including Pseudomonas azotoformans QDZ-1 [8], Acinetobacter sp. strain DL-2 [9], and Rhodococcus ruber JPL-2 [10]. Moreover, several genes encoding AOPP

pulicdomain/zero/1.0/) applies to the data made available in this article, unless otherwise stated. 
herbicide hydrolases that are involved in the degradation of AOPP herbicides have been identified [8-10]. To date, however, the metabolic pathway resulting in QPE degradation in microorganisms remains unclear and their QPE hydrolases have yet to be thoroughly investigated.

In the present study, we report the isolation and characterization of Pseudomonas sp. J-2, which can degrade QPE. For the first time, we also cloned and expressed a novel gene (qpeH) encoding a QPE hydrolase (QpeH) in E. coli BL21 (DE3). In addition, the characteristics of QpeH, including its substrate range and specificity were systematically investigated.

\section{Methods}

\section{Chemicals}

Quizalofop-p-ethyl ( $>97 \%$ purity) was kindly supplied by Fengle Agrochemical \& Chemical Co., Ltd. (He fei, China). Quizalofop-P-tefuryl, fenoxaprop-P-ethyl, haloxyfop-Pmethyl, cyhalofop-butyl, clodinafop-propargyl, diethyl pyrocarbonate (DEPC), phenylmethylsulfonyl fluoride (PMSF), 1,10-phenanthroline, and $N$-bromosuccinic acid (NBS) were purchased from Aladdin Industrial Inc. $p$-chloromercuribenzoic acid ( $\mathrm{pCMB}$ ) was purchased from the Shanghai Chemical Reagent Co., Ltd., China. All other chemicals and reagents were of analytical grade. Stock solutions of the above herbicides $(40 \mathrm{mM})$ were prepared in dimethyl sulfoxide and sterilized by filtration with a pore size of $0.22 \mu \mathrm{m}$. Luria-Bertani (LB) medium and mineral salts medium (MSM) were used in this study [11].

\section{Isolation and identification of QPE-degrading bacteria}

A soil sample $(10 \mathrm{~g})$ collected from the sewage outfall of the Fengle Agrochemical Co., Ltd. (He fei, China) was added to an Erlenmeyer flask $(250 \mathrm{~mL})$ containing $100 \mathrm{~mL}$ of MSM medium and QPE $\left(20 \mathrm{mg} \mathrm{L}^{-1}\right)$. After incubation for 7 days, the culture became turbid and $10 \mathrm{~mL}$ of the enrichment culture was transferred into another flask of fresh MSM medium containing $20 \mathrm{mg} \mathrm{L}^{-1} \mathrm{QPE}$. The rate of QPE removal was determined using high performance liquid chromatography (HPLC) as described below after the fourth transfer of the bacterial culture. A culture that degraded QPE was serially diluted and spread onto MSM agar plates containing $200 \mathrm{mg} \mathrm{L}^{-1} \mathrm{QPE}$. Colonies that grew on the plates were picked and purified by repeated streak plating. Isolates that possessed the highest QPEdegrading efficiency were selected and identified based on their morphological, physiological and biochemical properties combined with a $16 \mathrm{~S}$ rRNA gene sequence analysis as described by Lin et al. [12].

\section{Chemical analysis and identification of metabolites}

To determine the concentration of QPE, cells cultured in MSM were centrifuged $(1370 \times g, 5 \mathrm{~min})$ and the supernatants were extracted three times with an equal volume of dichloromethane. The aqueous layer was then acidified to $\mathrm{pH} 1.5-2.0$ by the addition of $2 \mathrm{~N}$ hydrochloric acid and re-extracted three times with an equal volume of dichloromethane. The extracts were combined and dried over anhydrous sodium sulfate and evaporated under reduced pressure. The residues were dissolved in a minimal volume of methanol and the solution was filtered through a $0.22-\mu \mathrm{m}$ Millipore membrane filter before analysis. All samples were analyzed by HPLC (Agilent 1260, USA) equipped with a $C_{18}$ reverse phase column $(150 \mathrm{~mm} \times 4.6 \mathrm{~mm} \times 5 \mu \mathrm{m})$ using a mobile phase consisting of methanol: water $(80: 20 \mathrm{v} / \mathrm{v})$ at a flow rate

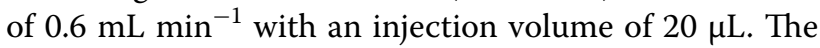
column was maintained at $25{ }^{\circ} \mathrm{C}$, and the UV detector was set at $236 \mathrm{~nm}$. The concentrations of other herbicides were determined according to the method of Nie et al. [8]. QPE metabolites were identified by a LC-IT-MS ${ }^{\mathrm{n}}$ system (Liquid Chromatography-Ion Trap Mass Spectrometry, Thermo, USA) as described by Stolker et al. [13].

\section{Cloning of the QPE-hydrolyzing esterase gene and data analysis}

General DNA manipulation was performed as described by Mamiatis et al. [14]. The QPE hydrolase gene from Pseudomonas sp. strain J-2 was cloned by first constructing a genomic DNA library using the shotgun method [9]. Bacterial genomic DNA was prepared using a high-salt extraction method [15] and subjected to partial digestion with the restriction enzyme Sau3AI. Fractions containing approximately 2- to 4-kb DNA fragments were isolated, purified, ligated into the BamHI site of the cloning vector pUC118, and transformed into competent E. coli DH5 $\alpha$ cells. Transformants were then plated onto LB agar plates supplemented with $100 \mathrm{mg} \mathrm{L}^{-1}$ of ampicillin and $200 \mathrm{mg} \mathrm{L}^{-1} \mathrm{QPE}$. The plates were incubated at $37^{\circ} \mathrm{C}$ for approximately $10 \mathrm{~h}$ and stored at $16^{\circ} \mathrm{C}$ for $48 \mathrm{~h}$ to allow transparent halos to be produced from QPE degrading colonies. Colonies exhibiting halos were picked and further tested by HPLC analysis for their QPE degradative ability. The selected positive clones were sequenced by Shanghai Sangon Biotech Co., Ltd. Nucleotide and deduced amino acid sequence analyses were performed using OMIGA 2.0 software (Oxford Molecular Ltd.). Blastn and Blastp tools (www.ncbi.nlm.nih.gov/Blast) were used for nucleotide sequencing and deduced amino acid sequence identity searches, respectively. Phylogenetic analysis of the protein sequences was performed using MEGA 6.0 software [16], and a bootstrap analysis including 1000 resamplings was used to evaluate the tree topology [17]. The presence of a signal peptide was predicted by the SignalP 4.1 server (http://www.cbs.dtu.dk/ services/SignalP/) [18]. 
Gene expression and purification of the recombinant QPE-hydrolyzing esterase

The qpeH gene was PCR-amplified from the genomic DNA of strain J-2 with PrimeSTAR HS DNA polymerase (TaKaRa) using the following primers: sense (5'-TT TGGATCCATGACCAAGATCTCTGCA-3), containing a $B a m H I$ I site (underlined) corresponding to positions 1-18; and antisense (5'-TTTCTCGAGGTCCTCGCGCT TCAGGAA-3'), containing a XhoI site (underlined) after the stop codon and a $6 \times$ His tag before the stop codon.

The qpeH PCR product was digested with $\mathrm{BamHI}$ and $X h o I$, and cloned into the expression vector pET-29a (+) to generate the recombinant plasmid pET-qpeH. QpeH was overexpressed in E. coli BL21 (DE3) using the HisBind protein fusion and purification system following the method described by Wang et al. [15]. The protein concentration was determined using the Bradford method with bovine serum albumin as a standard [19].

\section{Determination of the molecular mass and $\mathrm{pl}$}

The molecular mass of denatured QpeH was determined by sodium dodecyl sulfate-polyacrylamide gel electrophoresis (SDS-PAGE) according to the method by Laemmli [20]. SDS-PAGE gels were stained with Coomassie blue G-250 (Amresco, USA). The molecular mass of the native protein was determined by gel filtration [21]. The $\mathrm{p} I$ of QpeH was predicted using PAGE with $6.25 \%$ Ampholine (pH 3.5-10.0) (GE Healthcare, Sweden) in a gel strip $(0.5 \mathrm{~cm} \times 1.0 \mathrm{~cm})$ with an isoelectric focusing calibration kit (Pharmacia LKB Biotechnology), according to the supplier's recommendations.

\section{Enzyme assay}

All enzyme assays were performed in PBS $(50 \mathrm{mM} ; \mathrm{pH}$ 7.4), and no more than $10 \%$ of the substrate was hydrolyzed during each assay. For hydrolysis activity assays, 10 $\mu \mathrm{L}$ of QpeH $\left(0.12 \mathrm{mg} \mathrm{mL}^{-1}\right)$ was mixed with $0.08 \mathrm{mM}$ substrate in $10 \mathrm{~mL}$ of PBS, and the reaction mixture was incubated at $37^{\circ} \mathrm{C}$ for $1 \mathrm{~min}$. One unit of QpeH activity was defined as the amount of enzyme required to hydrolyze $1 \mu \mathrm{mol}$ of substrate per minute.

\section{Biochemical properties of the purified recombinant QpeH}

The optimal reaction $\mathrm{pH}$ was determined by incubating the reaction mixtures at $37{ }^{\circ} \mathrm{C}$ in the following buffers: $20 \mathrm{mM}$ citrate buffer, $\mathrm{pH}$ 3.0-6.0; $20 \mathrm{mM}$ PBS, $\mathrm{pH}$ 6.0-8.0; $20 \mathrm{mM}$ Tris- $\mathrm{HCl}$ buffer, $\mathrm{pH} 7.5-8.5$; and $50 \mathrm{mM}$ glycine- $\mathrm{NaOH}$ buffer, $\mathrm{pH}$ 8.5-11.0. The optimal reaction temperature was assessed using the optimal $\mathrm{pH}$ and incubating the reaction mixtures at different temperatures $\left(20-65^{\circ} \mathrm{C}\right)$ for $5 \mathrm{~min}$.

To determine $\mathrm{pH}$ stability, the enzyme was pre-incubated at $4{ }^{\circ} \mathrm{C}$ for $24 \mathrm{~h}$ in different buffers and the residual activity was assayed using the assay conditions described above.

To determine thermostability, the enzyme was incubated at different temperatures and aliquots were withdrawn at specific time intervals, with the remaining activity determined as described above. Non-heated enzyme was used as a control (100\%).

The effects of potential inhibitors or activators on the enzymatic activity of QpeH were analyzed by the addition of various metal salts and chemical agents to the reaction mixture, including $\mathrm{Fe}^{2+}, \mathrm{Ba}^{2+}, \mathrm{Cu}^{2+}, \mathrm{Li}^{+}, \mathrm{Fe}^{3+}, \mathrm{Co}^{2+}$, $\mathrm{Ni}^{2+}, \mathrm{Zn}^{2+}, \mathrm{Ca}^{2+}, \mathrm{Mg}^{2+}, \mathrm{Cr}^{2+}, \mathrm{Ag}^{+}$, and $\mathrm{Mn}^{2+}(1 \mathrm{mM})$; Tween-80, Triton X-100, SDS, EDTA, $\beta$-mercaptoethanol $(10 \mathrm{mM}), \mathrm{DEPC}$, PMSF, NBS, and pCMB $(0.5 \mathrm{mM})$. The reaction mixtures were pre-incubated for $30 \mathrm{~min}$ at $37^{\circ} \mathrm{C}$ with each inhibitor or activator and the enzymatic activity was assayed as described above. Enzyme activity without any additive was used as the control and was defined as $100 \%$.

\section{Determination of kinetic constants}

For kinetic studies, $0.8 \mu \mathrm{g}$ of purified enzyme was assayed at varying substrate concentrations for each substrate $(0.2-2.4 \mathrm{mM})$ at their optimal conditions. Kinetic parameters $\left(K_{m}\right.$ and $\left.V_{\text {max }}\right)$ were calculated using a LineweaverBurk plot [22]. The specificity constant, $k_{\text {cat }} / K_{m}$, was calculated to determine the substrate specificity for each substrate. Each experiment was carried out in triplicate and a control experiment without QpeH was performed under the same conditions. Kinetic analyses were performed by curve fitting with the Sigma Plot Kinetic Module (version 1.3). The standard error was recorded to be $<2 \%$.

\section{Nucleotide sequence accession numbers}

The nucleotide sequences of the 16S rRNA and the qpeH gene of Pseudomonas sp. strain J-2 have been deposited in the GenBank database (Accession Numbers KU522451 and KU522452, respectively).

\section{Results and discussion} Isolation and characterization of the QPE-degrading strain Quizalofop-p-ethyl has been widely used as an herbicide in the Anhui Province, China for many years. QPE residues have frequently been found in the soil; therefore, it is probable that several microbes may have adapted to this QPE-contaminated environment. After approximately 1 month of enrichment and isolation, four pure isolates that grew using QPE as the sole carbon and energy source were obtained from the acclimated activated sludge. The ability of these four strains to degrade QPE was confirmed in liquid MSM medium supplemented with QPE. One isolate, designated J-2, showed 
the highest QPE-degrading ability and was selected for subsequent experiments. Basic biochemical tests showed that strain J-2 consisted of Gram-negative rods that were positive for catalase-, oxidase, and nitrate reductase activity. Cells grew aerobically, were $1.8-2.0 \mu \mathrm{m}$ long and $0.7-0.9 \mu \mathrm{m}$ wide, and were motile with one polar flagellum. Optimal growth of strain J-2 was observed at $\mathrm{pH}$ 7.0, with a $\mathrm{NaCl}$ concentration of $0 \%(\mathrm{w} / \mathrm{v})$, at $28{ }^{\circ} \mathrm{C}$ in LN medium (LB without $\mathrm{NaCl}$ ) supplemented with $0-5 \%$ $(\mathrm{w} / \mathrm{v}) \mathrm{NaCl}$. Phylogenetic analysis of the $16 \mathrm{~S}$ rRNA gene sequence revealed that strain $\mathrm{J}-2$ was closely affiliated with Pseudomonas sp. and was most closely related to Pseudomonas zhaodongensis with a similarity of $99.10 \%$ (data not shown).

Pseudomonas are ubiquitous and numerous in soil and can survive under extremely harsh conditions. Moreover, members of the genus Pseudomonas consists of a number of well-studied degraders of organic pollutants in the environment [23]. For example phenanthrene can be degraded by Pseudomonas sp. JM2 [23] and Pseudomonas stutzeri strain ZP2 [24], nicotine by Pseudomonas sp. strain HF-1 [25], pyrene by Pseudomonas sp. strain Jpyr-1 [26], and sulfadoxine by Pseudomonas sp. DX7 [27]. In this study, a pure bacterial strain identified to the genus Pseudomonas was isolated and efficiently degraded QPE. These features make them ideal candidates for the bioremediation of contaminated environments.

\section{Cloning and sequence analysis of the QPE-hydrolase gene}

To clone the QPE-hydrolase gene, a genomic library of strain J-2 was constructed as previously described [15] and one positive clone that produced a transparent halo around the colony was identified from approximately 20,000 transformants. The ability of this strain to degrade QPE was confirmed by HPLC and a plasmid from this strain was extracted and subjected to DNA sequencing. The results showed that the inserted fragment in the transformant was 2086 bp long and contained two complete ORFs. The two identified ORFs were then subcloned into the vector pMD18-T and transformed into $E$. coli DH5 $\alpha$. One of the ORFs was identified as the structural gene encoding QPE hydrolase and was designated as $q p e H$.

The cloned $q p e H$ gene was $930 \mathrm{bp}$ in length with a GC content of $70.1 \%$ and encoded a protein of 309 amino acids with a calculated molecular mass of $32,831 \mathrm{Da}$. A

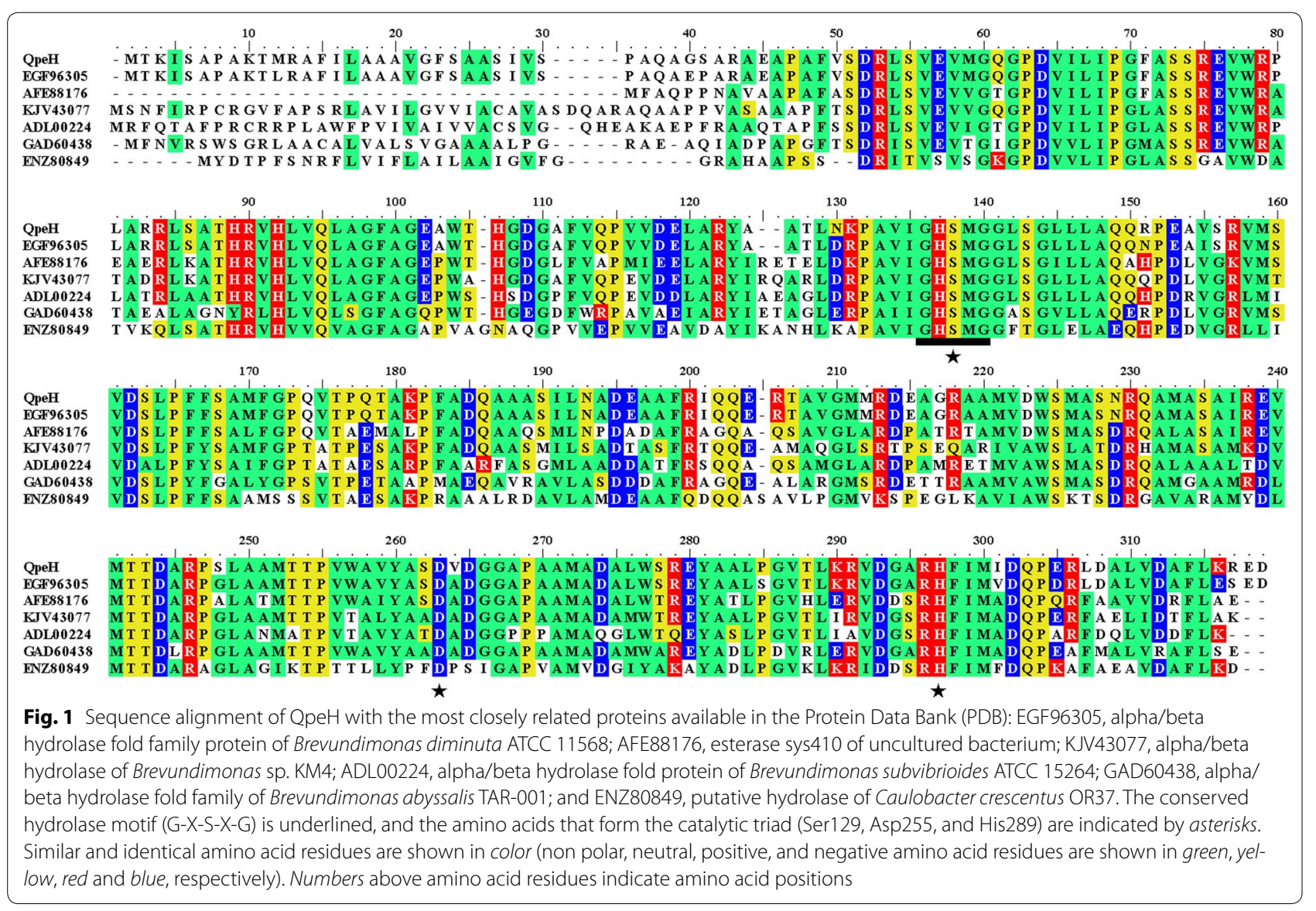




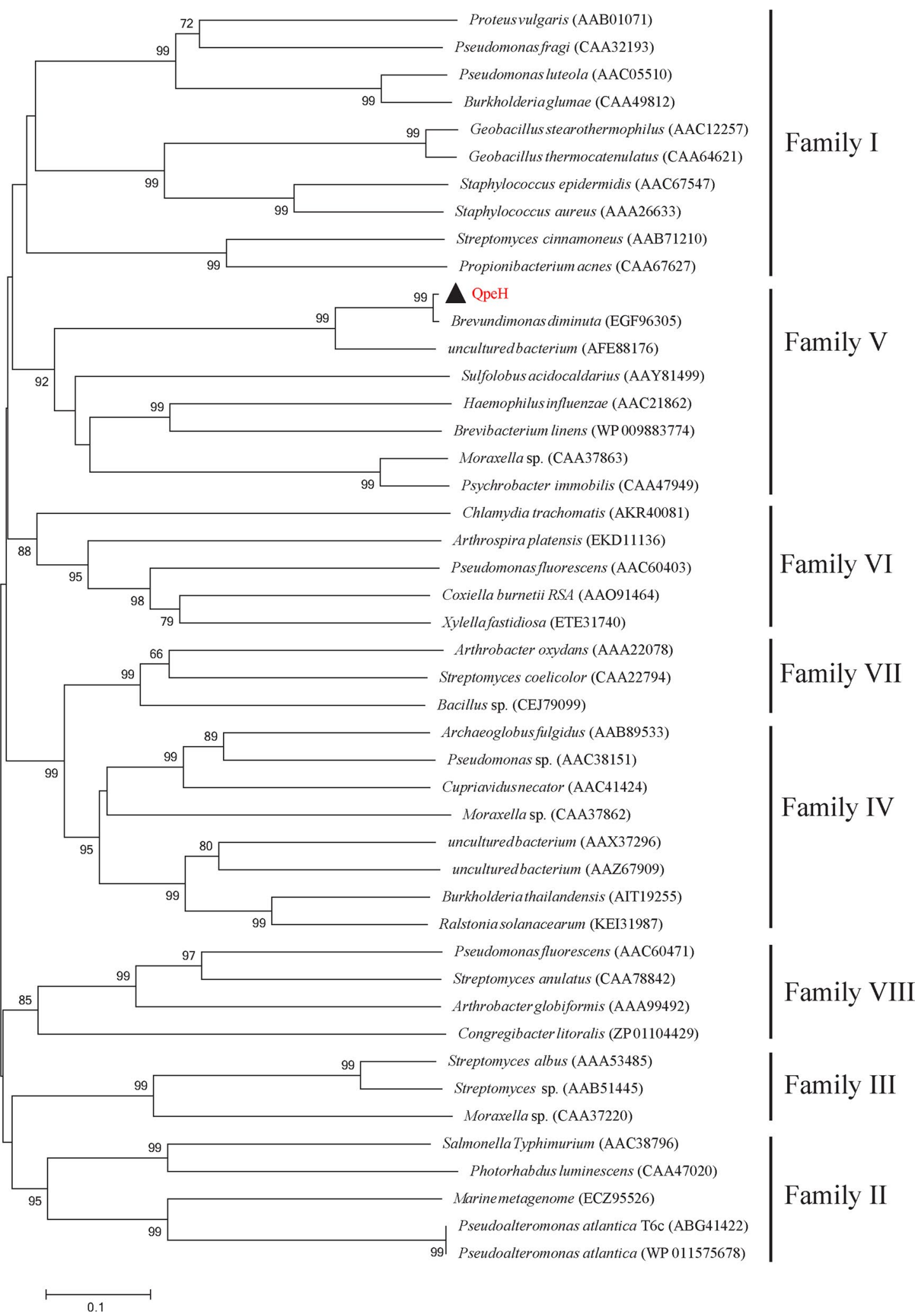

Fig. 2 Phylogenetic analysis of QpeH demonstrating its relation to other esterases from subfamilies I-VIII. The phylogenetic tree was constructed using the neighbor-joining method with 1000 bootstrap replicates (values $>60 \%$ are shown at the nodes). The related protein sequences retrieved from GenBank were aligned using ClustalW Bar, 0.1 
putative signal peptide was identified at the $\mathrm{N}$ terminus by using the SignalP 4.1 server, with the most likely cleavage site situated between amino acids Ala33 and Gly34, resulting in a putative 276-residue mature protein. The corresponding protein was used as a query sequence in a homology search against the Protein Data Bank (NCBI database). This search revealed that the most closely related proteins were several hypothetical proteins (hydrolases or esterases); for example, $\alpha / \beta$ hydrolase from Brevundimonas diminuta (89\%), esterase sys410 from uncultured bacterium (76\%), and lactofen hydrolase from Brevundimonas sp. LY-2 (72\%). Recently, cloning of the novel gene $c h b H$, encoding a cyhalofopbutyl hydrolase, from $P$. azotoformans strain QDZ-1 was reported [8]. ChbH hydrolyzed all AOPP herbicides tested, including QPE, with a specific activity of $4.12 \pm 0.25 \mu \mathrm{mol} \mathrm{min}^{-1} \mathrm{mg}^{-1}$ [8]. A novel carboxylesterase encoding gene $(f e h)$ was cloned from $R$. ruber strain JPL-2 and FeH had a broader substrate spectrum and higher catalytic efficiency toward AOPP herbicides [10]. In the same year, another novel FE hydrolase/esterase, AfeH, which also hydrolyzed various AOPP herbicides and belonged to family VII of lipolytic enzymes, was characterized [9]. In the present study, QpeH from strain $\mathrm{J}-2$ had 7.9 and $9.3 \%$ similarity to that of $\mathrm{FeH}$ and $\mathrm{ChbH}$, respectively, but only showed $5.8 \%$ similarity to $\mathrm{AfeH}$.

QpeH also contained the conserved esterase family sequence motif (G-X-S-X-G) (Fig. 1) [28]. Moreover, a catalytic triad that is also highly conserved in this enzyme family [29], Ser-Asp-His (Ser129, Asp255, and His289), was also identified. Bacterial lipase/esterase proteins have been classified into eight different families based on their amino acid sequences and biochemical properties [30]. A phylogenetic tree was constructed to verify the evolutionary relationship between $\mathrm{QpeH}$ and its closest relatives, as well as to characterize members of the esterase family [31]. Based on these data, QpeH was shown to be a novel QPE hydrolase that belongs to family $\mathrm{V}$, and which is completely different from FeH from $R$. ruber strain JPL-2, ChbH from $P$. azotoformans QDZ-1 and AfeH from Acinetobacter sp. strain DL-2, based on amino acid sequence comparisons and phylogenetic analyses (Fig. 2).

\section{Expression and purification of recombinant QpeH}

Recombinant QpeH was produced in E. coli BL21 (DE3) and purified from the crude extract using Ni-nitrilotriacetic acid affinity chromatography. The purified enzyme gave a single band on SDS-PAGE (Fig. 3). The molecular mass of recombinant QpeH was approximately $39 \mathrm{kDa}$, which was consistent with the molecular mass deduced from the amino acid sequence $(38,500 \mathrm{Da})$. The estimated molecular mass of the native enzyme was also approximately $39 \mathrm{kDa}$ as determined by gel filtration, which suggested that the enzyme was a monomer. Furthermore, the $\mathrm{p} I$ value of $\mathrm{QpeH}$ was 6.7 by isoelectric focusing. QpeH was similar in size to other reported hydrolases, such as AfeH (34 kDa) from Acinetobacter sp. strain DL-2 [9], ChbH (36 kDa) from P. azotoformans strain QDZ-1 [8] and PytH $(31 \mathrm{kDa})$ from Sphingobium sp. strain JZ-1 [32]. In addition, the metabolites were identified by LC-IT-MS ${ }^{\text {n }}$. These results indicated that QpeH catalyzed the hydrolysis of QPE to quizalofop acid (QA) and ethanol (Fig. 4).

\section{Characteristics of QpeH}

Environmental factors such as $\mathrm{pH}$ and temperature can affect enzyme activity and stability [33]. The recombinant QpeH exhibited high levels of activity at $\mathrm{pH}$ 7.58.5 , with an optimum $\mathrm{pH}$ of 8.0 (Fig. 5a). Little activity was detected at $\mathrm{pH}$ values below 4.0 or above 13.0. The enzyme retained more than $85 \%$ of the original activity after pre-incubation in a buffer at a $\mathrm{pH}$ range below 4.0 or above 13.0 for $1 \mathrm{~h}$ (Fig. 5a).

The enzyme was active at $20-65{ }^{\circ} \mathrm{C}$, with an optimum temperature of $30{ }^{\circ} \mathrm{C}$ (Fig. $5 \mathrm{~b}$ ). The thermal stability of the purified enzyme was assayed by incubating QpeH for $10 \mathrm{~h}$ between 20 and $45^{\circ} \mathrm{C}$ in the absence of QPE (Fig. 5b). QpeH was stable and retained $>50 \%$ of its residual activity after $10 \mathrm{~h}$ at temperatures $<30{ }^{\circ} \mathrm{C}$, but was unstable at temperatures $>50^{\circ} \mathrm{C}$, suggesting $\mathrm{QpeH}$ is a mesophilic enzyme. In this study, QpeH exerted high activity and stability over a broad $\mathrm{pH}$ and temperature range.

The substrate specificity of QpeH was assessed with various aryloxyphenoxy propanoate AOPP herbicides as

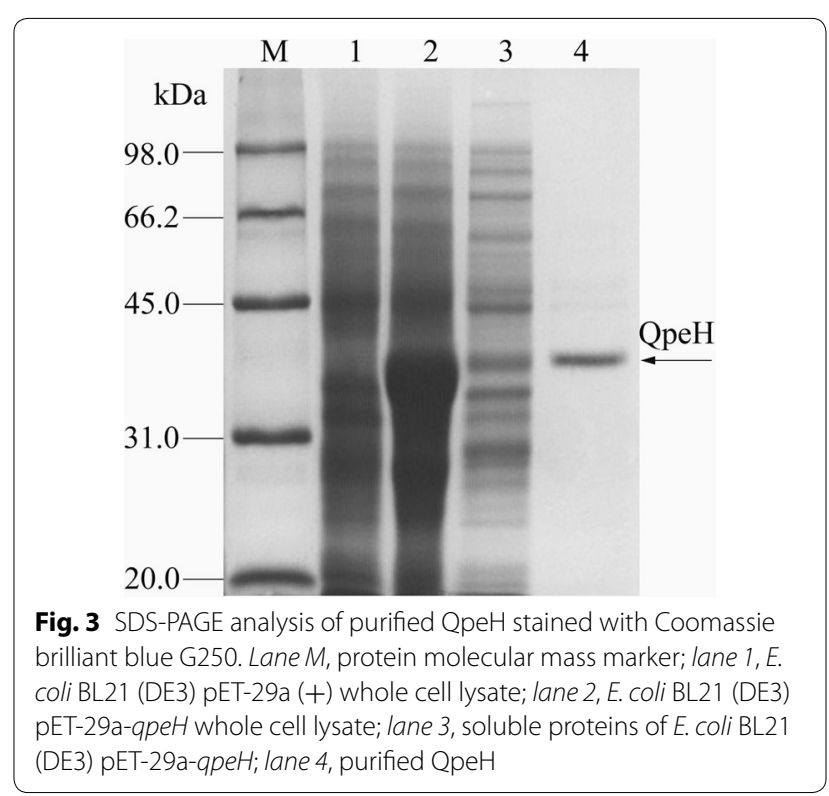


Chang et al. Microb Cell Fact (2017) 16:80

Page 7 of 10

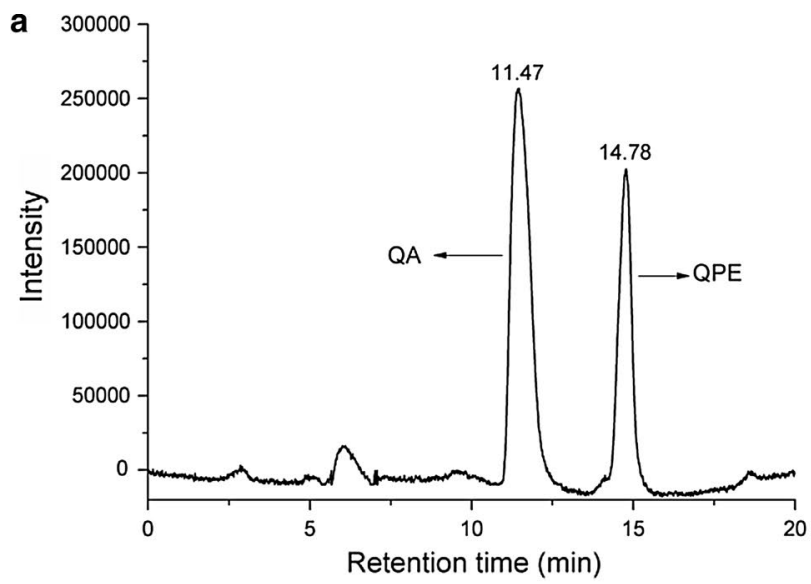

b

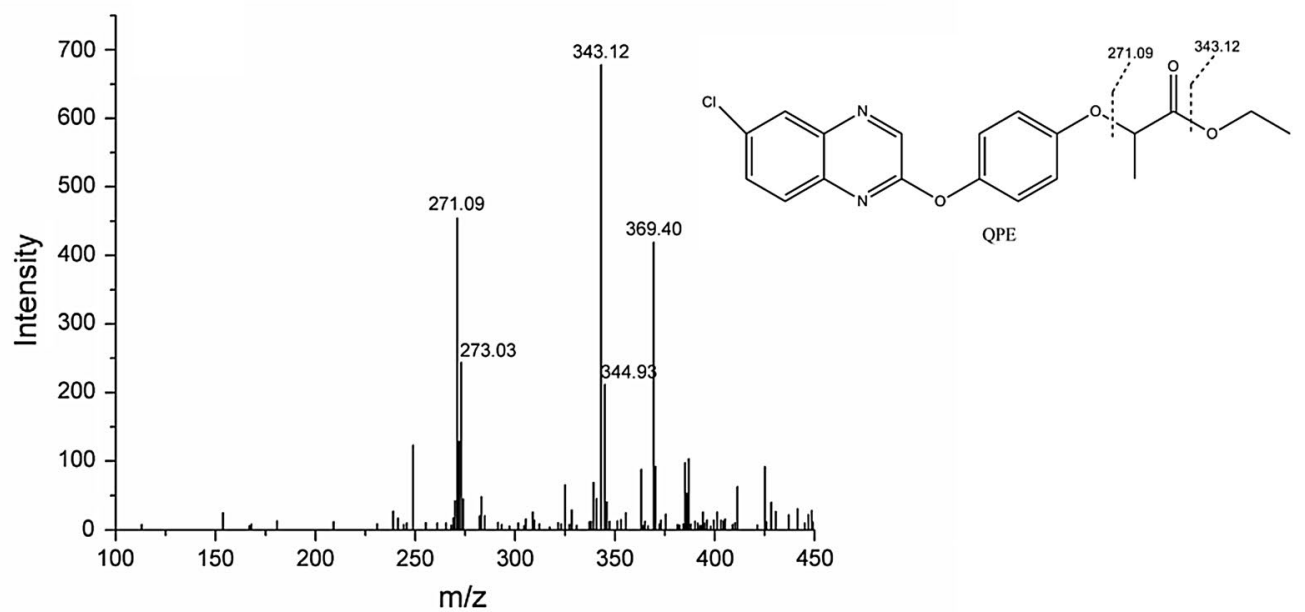

C

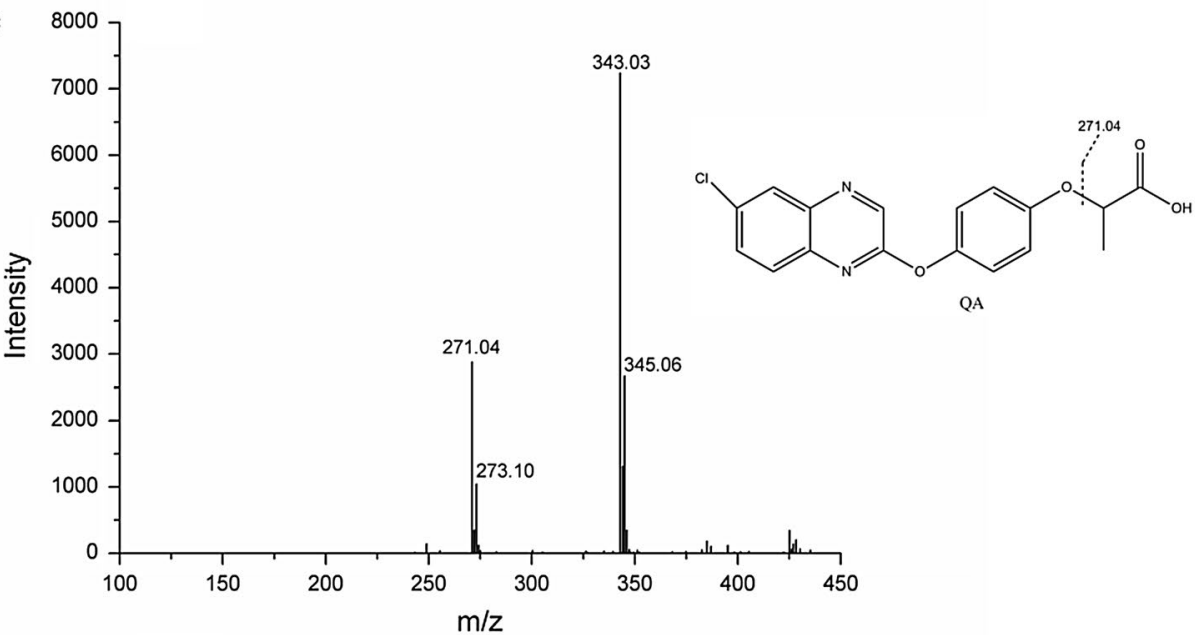

d

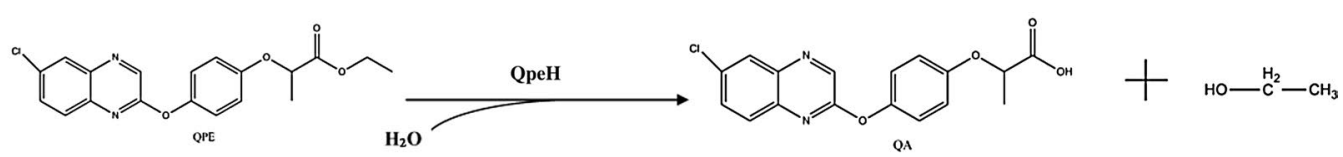

Fig. 4 LC -MS analysis of QPE intermediates resulting from QpeH hydrolysis of the substrate and a proposed metabolic pathway. a $L C$ profiles for QPE and its intermediate identified as QA. b-c Mass spectrum of characteristic ions for QPE (RT = $14.78 \mathrm{~min}$ ) and the metabolite QA (RT = 11.47 min). d Proposed pathway of QPE hydrolysis by QpeH. QPE is converted to QA and ethanol by hydrolysis 

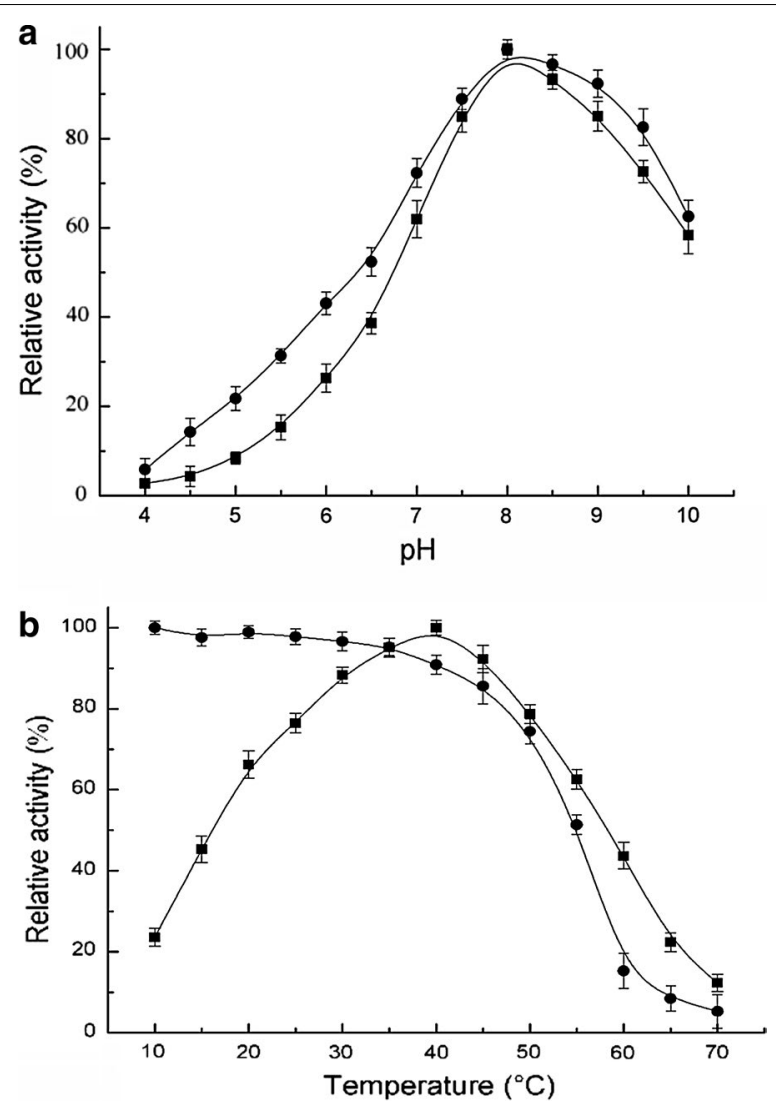

Fig. 5 Effects of pH (a) and temperature (b) on QpeH activity (closed squares) and stability (closed circles). QPE was used as the substrate in all reactions. The values are shown as a percentage of the maximum activity (100\%)

substrates (Table 1). QpeH hydrolyzed all AOPP herbicides tested, with different hydrolysis rates in descending order as follows: fenoxaprop-P-ethyl $>$ quizalofop-P-tefuryl $>$ QPE $>$ haloxyfop-P-methyl > cyhalofop-butyl $>$ clodinafop-propargyl (Table 1). This result indicated that the enzyme has potential applications in the in situ bioremediation of AOPP herbicide residues. The specific activity of QpeH for different herbicides was $198.9 \pm 2.7 \mathrm{U} \mathrm{mg}^{-1}$ for QPE and $257.2 \pm 3.7 \mathrm{U} \mathrm{mg}^{-1}$ for fenoxaprop-P-ethyl.
The most suitable substrate was fenoxaprop-P-ethyl with $K_{m}$ and $K_{c a t}$ values of $26.9 \pm 4.3 \mu \mathrm{M}$ and $161.6 \pm 3.4 \mathrm{~s}^{-1}$, respectively. The specific activities of other enzymes for fenoxaprop-P-ethyl were $1080 \mathrm{U} \mathrm{mg}^{-1}$ for $\mathrm{FeH}$ and $3.95 \pm 0.21 \mathrm{mg}^{-1}$ for the cyhalofop-butyl-hydrolyzing esterase, $\mathrm{ChbH}[8,10]$.

Metal ions often play a key role in the activity of enzymes. As shown in Table 2, $1 \mathrm{mM} \mathrm{Ca}^{2+}$ and $\mathrm{Cd}^{2+}$ strongly stimulated QpeH enzyme activity, while $\mathrm{Li}^{+}$, $\mathrm{Fe}^{3+}$ and $\mathrm{Co}^{2+}$ also slightly increased enzymatic activity. However, $\mathrm{Ba}^{2+}$ and $\mathrm{Ag}^{+}$reduced QpeH activity slightly, while $\mathrm{Ni}^{2+}, \mathrm{Fe}^{2+}$, and $\mathrm{Ag}^{+}$were strongly inhibitory for QpeH. $\mathrm{Cu}^{2+}, \mathrm{Mn}^{2+}$, and $\mathrm{Zn}^{2+}$ ions had little effect on the enzyme activity at a concentration of $1 \mathrm{mM}$.

The effect of various chemical agents on enzyme activity was also investigated. QpeH had no apparent requirement for metal ions because the chelating agents EDTA and 1,10-phenanthroline had little effect on enzyme activity [32]. Treatment of QpeH with $10 \mathrm{mM}$ DEPC resulted in a complete loss of catalytic activity, which indicated the involvement of His residues in the active sites of the enzyme [34]. The surfactants SDS, Tween 80, Triton X $100(10 \mathrm{mM})$, and $\beta$-mercaptoethanol $(10 \mathrm{mM})$ all strongly inhibited QpeH activity, as did the Ser protease inhibitor PMSF and the thiol reagent $\mathrm{PCMB}$ $(10 \mathrm{mM})$. Chemical modification of QpeH with $10 \mathrm{mM}$ NBS resulted in a $70 \%$ inhibition of catalytic activity (Table 3).

Table 2 Effect of metal ions on QpeH enzyme activity

\begin{tabular}{lllr}
\hline Substances & $\begin{array}{l}\text { Relative } \\
\text { activity (\%) }\end{array}$ & Substances & $\begin{array}{c}\text { Relative } \\
\text { activity (\%) }\end{array}$ \\
\hline None & 100 & $1 \mathrm{mM} \mathrm{Ba}^{2+}$ & $86 \pm 1.7$ \\
$1 \mathrm{mM} \mathrm{Ca}^{2+}$ & $167 \pm 2.1$ & $1 \mathrm{mM} \mathrm{Mn}^{2+}$ & $91 \pm 1.6$ \\
$1 \mathrm{mM} \mathrm{Ni}^{2+}$ & $63 \pm 1.5$ & $1 \mathrm{mM} \mathrm{Li}^{+}$ & $122 \pm 2.9$ \\
$1 \mathrm{mM} \mathrm{Cu}^{2+}$ & $97 \pm 1.3$ & $1 \mathrm{mM} \mathrm{Zn}^{2+}$ & $97 \pm 1.5$ \\
$1 \mathrm{mM} \mathrm{Fe}^{2+}$ & $72 \pm 2.3$ & $1 \mathrm{mM} \mathrm{Cd}^{2+}$ & $152 \pm 1.6$ \\
$1 \mathrm{mM} \mathrm{Fe}^{3+}$ & $116 \pm 2.2$ & $1 \mathrm{mM} \mathrm{Co}^{2+}$ & $113 \pm 2.2$ \\
$1 \mathrm{mM} \mathrm{Mg}^{2+}$ & $80 \pm 1.8$ & $1 \mathrm{mM} \mathrm{Ag}^{+}$ & $36 \pm 1.3$ \\
\hline
\end{tabular}

Table 1 Kinetic parameters for the hydrolysis of various AOPP herbicides

\begin{tabular}{|c|c|c|c|c|}
\hline & $K_{\mathrm{m}}(\mu \mathrm{M})$ & $K_{\text {cat }}\left(\mathrm{s}^{-1}\right)$ & $K_{\mathrm{cat}} / K_{\mathrm{m}}\left(\mathrm{s}^{-1} \mu \mathrm{M}^{-1}\right)$ & $\begin{array}{l}\text { Enzyme activity } \\
\text { (U/mg) }\end{array}$ \\
\hline QPE & $41.3 \pm 3.6$ & $127.3 \pm 4.5$ & $3.08 \pm 0.03$ & $198.9 \pm 2.7$ \\
\hline Quizalofop-P-tefuryl & $29.5 \pm 2.7$ & $146.4 \pm 3.3$ & $4.96 \pm 0.09$ & $238.1 \pm 4.1$ \\
\hline Fenoxaprop-P-ethyl & $26.9 \pm 4.3$ & $161.6 \pm 3.4$ & $6.01 \pm 0.05$ & $257.2 \pm 3.7$ \\
\hline Haloxyfop-P-methyl & $113.9 \pm 3.8$ & $67.4 \pm 2.6$ & $0.59 \pm 0.04$ & $64.7 \pm 2.4$ \\
\hline Cyhalofop-butyl & $158.2 \pm 3.5$ & $41.1 \pm 4.1$ & $0.26 \pm 0.03$ & $48.6 \pm 3.1$ \\
\hline Clodinafop-propargyl & $174.0 \pm 4.2$ & $37.1 \pm 2.9$ & $0.21 \pm 0.02$ & $42.3 \pm 2.8$ \\
\hline
\end{tabular}


Table 3 Effect of chemical agents on QpeH enzyme activity

\begin{tabular}{llll}
\hline Substances & $\begin{array}{l}\text { Relative } \\
\text { activity (\%) }\end{array}$ & Substances & $\begin{array}{l}\text { Relative } \\
\text { activity (\%) }\end{array}$ \\
\hline None & 100 & $\begin{array}{c}\text { 10mM1, 10- } \\
\text { phenanthroline }\end{array}$ & $96 \pm 1.4$ \\
$10 \mathrm{mM}$ EDTA & $93 \pm 0.3$ & $\begin{array}{c}10 \mathrm{mM} \mathrm{NBS} \\
10 \mathrm{mM} \mathrm{PCMB}\end{array}$ & $29 \pm 2.1$ \\
$10 \mathrm{mM}$ & $43 \pm 1.3$ & & \\
$\quad \begin{array}{l}\text { B-mercaptoethanol } \\
10 \mathrm{mM} \text { Tween } 80\end{array}$ & $13 \pm 0.9$ & $10 \mathrm{mM} \mathrm{PMSF}$ & $23 \pm 1.7$ \\
$10 \mathrm{mM}$ SDS & $7.7 \pm 1.7$ & $10 \mathrm{mM} \mathrm{DEPC}$ & $0.5 \pm 0.2$ \\
10 mM Triton X 100 & $3.1 \pm 1.1$ & & \\
\hline
\end{tabular}

\section{Authors' contributions}

GW conceived and designed the experiments. $\mathrm{HZ}$ and $\mathrm{ML}$ performed the experiments. GW wrote the manuscript. GW, ML, JL and YL analyzed the data. All authors reviewed the manuscript. All authors read and approved the final manuscript.

\section{Acknowledgements}

We want to thank Feng Li for fruitful discussions on experimental design for enzymatic assays, Dayong Xu for critical reading of the manuscript.

\section{Competing interests}

The authors declare that they have no competing interests.

\section{Availability of data and materials}

All materials described within this manuscript, and engineered strains are available on request.

\section{Consent for publication}

Our manuscript does not contain any individual person's data in any form.

\section{Ethics approval and consent to participate}

Our manuscript does not report data collected from humans or animals.

\section{Funding}

This work was supported by grants from the Chinese National Natural Science Foundation (31100083 and 41501304), the Natural Science Foundation from Educational Commission of Anhui Province (KJ2015A049), and Provincial Natural Science Foundation of Anhui (1508085MC49).

\section{Publisher's Note}

Springer Nature remains neutral with regard to jurisdictional claims in published maps and institutional affiliations.

Received: 2 November 2016 Accepted: 4 May 2017

Published online: 10 May 2017

\section{References}

1. Min Z. Initial study of preventing and eliminating weeds of the grass family in cotton fields with 10\% quizalofop-ethyl EC. Pesticides. 2003;1:015.

2. Zhang H, Li M, Li J, Wang GL, Li F, Xu DY, Liu Y, Xiong MH. A key esterase required for the mineralization of quizalofop-p-ethyl by a natural consortium of Rhodococcus sp. JT-3 and Brevundimonas sp. JT-9. J Hazard Mater. 2017:327:1-10.

3. Zeng D, Shi H, Li B, Wang M, Song B. Development of an enzyme-linked immunosorbent assay for quantitative determination of quizalofopp-ethyl. J Agric Food Chem. 2006;54:8682-7.
4. Elefsiniotis IS, Liatsos GD, Stamelakis D, Moulakakis A. Case report: mixed cholestatic/hepatocellular liver injury induced by the herbicide quizalofop-p-ethyl. Environ Health Perspect. 2007;115:1479-81.

5. Mustafa Y, Suna Arikan E. Genotoxicity testing of quizalofop-P-ethyl herbicide using the Allium cepa anaphase-telophase chromosome aberration assay. Caryologia. 2008;61:45-52.

6. Doganlar ZB. Quizalofop-p-ethyl-induced phytotoxicity and genotoxicity in Lemna minor and Lemna gibba. J Environ Sci Health Part A. 2012;47:1631-43.

7. Ding CX, Gong DX, Xiao H, Ren YJ, Wang J, Peng WJ, Tang WB. Determination of quizafop-p-ethyl residue in soil and tobacco by high performance liquid chromatography. Appl Chem Ind. 2012;11:041.

8. Nie ZJ, Hang BJ, Cai S, Xie XT, He J, Li SP. Degradation of cyhalofop-butyl (CyB) by Pseudomonas azotoformans strain QDZ-1 and cloning of a novel gene encoding CyB-hydrolyzing esterase. J Agric Food Chem. 2011;59:6040-6.

9. Dong W, Jiang S, Shi K, Wang F, Li S, Zhou J, Huang F, Wang Y, Zheng Y, Hou Y. Biodegradation of fenoxaprop-P-ethyl (FE) by Acinetobacter sp. strain DL-2 and cloning of FE hydrolase gene afeH. Bioresour Technol. 2015;186:114-21.

10. Liu HM, Lou Xu, Ge ZJ, Yang F, Chen DB, Zhu JC, Xu JH, Li SP, Hong Q. Isolation of an aryloxyphenoxy propanoate (AOPP) herbicide-degrading strain Rhodococcus ruber JPL-2 and the cloning of a novel carboxylesterase gene (feh). Braz J Microbiol. 2015;46:425-32.

11. Wang G, Yue W, Liu Y, Li F, Xiong M, Zhang H. Biodegradation of the neonicotinoid insecticide Acetamiprid by bacterium Pigmentiphaga sp. strain AAP-1 isolated from soil. Bioresour Technol. 2013;138:359-68.

12. Lin SY, Hameed A, Hung MH, Liu YC, Hsu YH, Young LS, Young CC. Pseudomonas matsuisoli sp. nov., isolated from a soil sample. Int J Syst Evol Microbiol. 2015;65:902-9.

13. Stolker A, Van Schoonhoven J, De Vries A, Bobeldijk-Pastorova I, Vaes W, Van Den Berg R. Determination of cannabinoids in cannabis products using liquid chromatography-ion trap mass spectrometry. J Chromatogr A. 2004;1058:143-51.

14. Mamiatis T, Fritsch E-F, Sambrook J, Engel J. Molecular cloning—a laboratory manual. New York: Cold Spring Harbor Laboratory; 1982, 545 S., $42 \$[J]$ (1985).

15. Wang G, Li R, Li S, Jiang J. A novel hydrolytic dehalogenase for the chlorinated aromatic compound chlorothalonil. J Bacteriol. 2010;192:2737-45

16. Tamura K, Stecher G, Peterson D, Filipski A, Kumar S. MEGA6: molecular evolutionary genetics analysis version 6.0. Mol Biol Evol. 2013;30:2725-9.

17. Zhang J, Yin J-G, Hang B-J, Cai S, He J, Zhou S-G, Li S-P. Cloning of a novel arylamidase gene from Paracoccus sp. strain FLN-7 that hydrolyzes amide pesticides. Appl Environ Microbiol. 2012;78:4848-55.

18. Petersen TN, Brunak S, von Heijne G, Nielsen H. SignalP 4.0: discriminating signal peptides from transmembrane regions. Nat Methods. 2011;8:785-6.

19. Bradford MM. A rapid and sensitive method for the quantitation of microgram quantities of protein utilizing the principle of protein-dye binding. Anal Biochem. 1976;72:248-54.

20. Laemmli UK. Cleavage of structural proteins during the assembly of the head of bacteriophage T4. Nature. 1970;227:680-5.

21. Wu PC, Liu YH, Wang ZY, Zhang XY, Li H, Liang WQ, Luo N, Hu JM, Lu JQ, Luan TG. Molecular cloning, purification, and biochemical characterization of a novel pyrethroid-hydrolyzing esterase from Klebsiella sp. strain ZD112. J Agric Food Chem. 2006;54:836-42.

22. Dowd JE, Riggs DS. A comparison of estimates of Michaelis-Menten kinetic constants from various linear transformations. J Biol Chem. 1965;240:863-9.

23. Ma J, Xu L, Jia L. Degradation of polycyclic aromatic hydrocarbons by Pseudomonas sp. JM2 isolated from active sewage sludge of chemical plant. J Environ Sci. 2012;24:2141-8.

24. Zhao HP, Wu QS, Wang L, Zhao XT, Gao HW. Degradation of phenanthrene by bacterial strain isolated from soil in oil refinery fields in Shanghai China. J Hazard Mater. 2009;164:863-9.

25. Ruan A, Min H, Peng X, Huang Z. Isolation and characterization of Pseudomonas sp. strain HF-1, capable of degrading nicotine. Res Microbiol. 2005;156:700-6. 
26. Ma J, Xu L, Jia L. Characterization of pyrene degradation by Pseudomonas sp. strain Jpyr-1 isolated from active sewage sludge. Bioresour Technol. 2013;140:15-21.

27. Zhang W, Xu D, Niu Z, Yin K, Liu P, Chen L. Isolation and characterization of Pseudomonas sp. DX7 capable of degrading sulfadoxine. Biodegradation. 2012;23:431-9.

28. Wang F, Hou Y, Zhou J, Li Z, Huang Y, Cui Z. Purification of an amide hydrolase DamH from Delftia sp. T3-6 and its gene cloning, expression, and biochemical characterization. Appl Microbiol Biotechnol. 2014;98:7491-9.

29. Xue Y, Zhang J, Wu X, Sun H, Xu C. Cloning, expression and characterization of a novel esterase from Bacillus pumilus. Ann Microbiol. 2013;63:879-85.

30. Arpigny J, Jaeger K. Bacterial lipolytic enzymes: classification and properties. Biochem J. 1999;343:177-83.
31. Glogauer A, Martini VP, Faoro H, Couto GH, Müller-Santos M, Monteiro RA, Mitchell DA, de Souza E, Pedrosa F, Krieger N. Identification and characterization of a new true lipase isolated through metagenomic approach. Microb Cell Fact. 2011;10:54.

32. Wang BZ, Guo P, Hang BJ, Li L, He J, Li SP. Cloning of a novel pyrethroidhydrolyzing carboxylesterase gene from Sphingobium sp. strain JZ-1 and characterization of the gene product. Appl Environ Microbiol. 2009;75:5496-500.

33. Zhao B, Hua X, Wang F, Dong W, Li Z, Yang Y, Cui Z, Wang M. Biodegradation of propyzamide by Comamonas testosteroni $W 1$ and cloning of the propyzamide hydrolase gene camH. Bioresour Technol. 2015;179:144-9.

34. Yang G, Liu RQ, Taylor KL, Xiang H, Price J, Dunaway-Mariano D. Identification of active site residues essential to 4-chlorobenzoyl-coenzyme A dehalogenase catalysis by chemical modification and site directed mutagenesis. Biochemistry. 1996;35:10879-85.

\section{Submit your next manuscript to BioMed Central and we will help you at every step:}

- We accept pre-submission inquiries

- Our selector tool helps you to find the most relevant journal

- We provide round the clock customer support

- Convenient online submission

- Thorough peer review

- Inclusion in PubMed and all major indexing services

- Maximum visibility for your research

Submit your manuscript at www.biomedcentral com/submit 